\title{
Effects of Happiness Levels in Asia
}

\section{M.Rully Firmansyah*, Dyah Wulansari}

Economics Department, Economic and Business Faculty, Airlangga University, Indonesia

* Corresponding author: rulyfirmansyah@yahoo.com

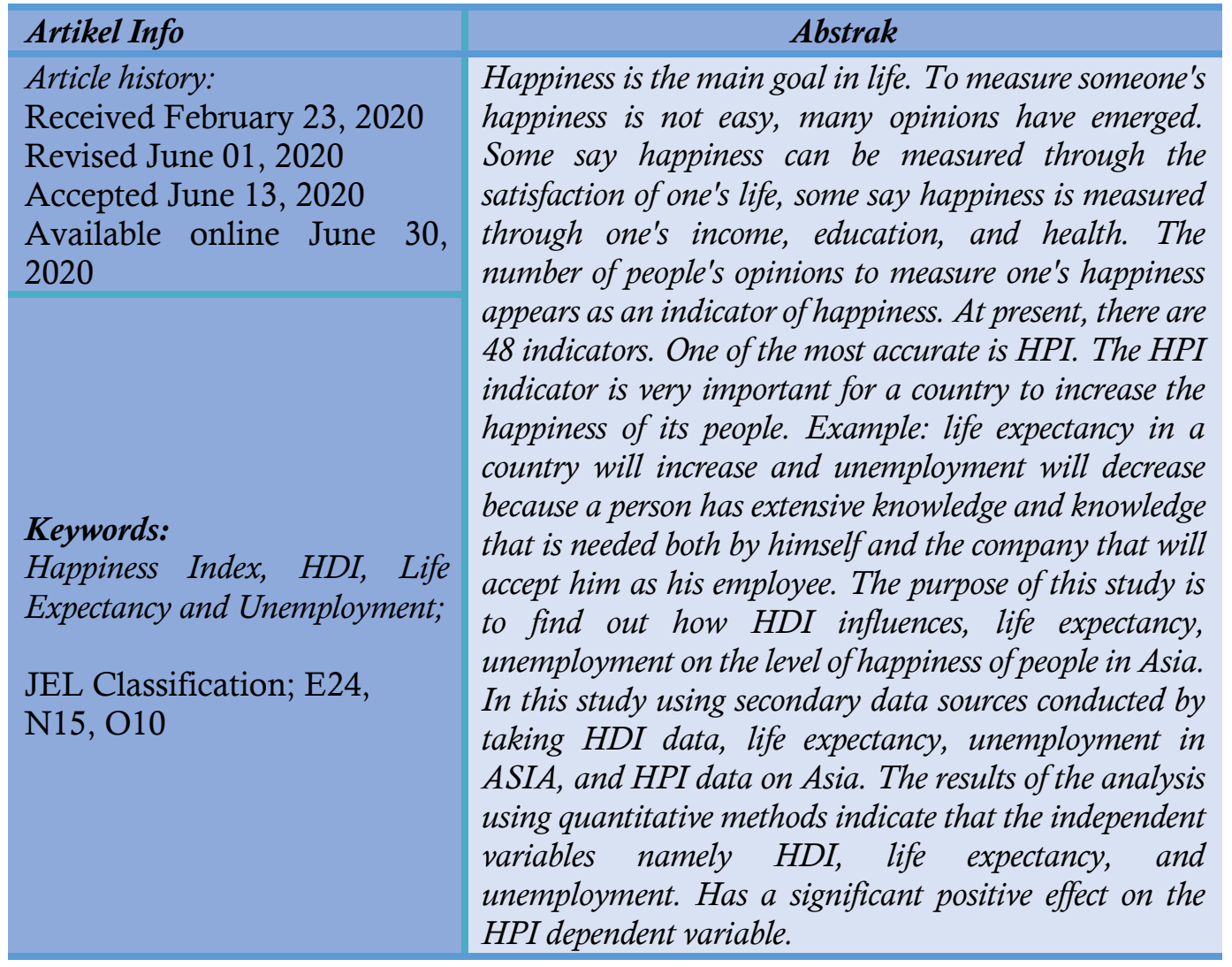

\section{INTRODUCTION}

Happiness is considered by many to be the ultimate goal in life; indeed, almost everyone wants to be happy. In the Declaration of American Independence, it was revealed clearly that happiness is an absolute right that is comparable to life and freedom. In the late 1980s, the fourth king of Bhutan, Jigme Singye Wangchuck, pronounced Gross National Happiness as a principle applicable in his country (Ura, 2004).

Currently, the happiness index uses income achievement only. The paradox of happiness or income paradox, known as the Easterlin Paradox, which is an increase in income can increase one's welfare or happiness. (Clark A. E., 2008) also found the same thing in the United States. The existence of the Easterlin paradox shows that there are other factors besides income (material) that affect happiness. Absolute income is not an important determinant of happiness but relative income, income comparison (Clark A. D., 2011). The author wants to prove that not only does income affect someone who is said to be happy, but other factors contain someone happy.

The difference between the research conducted and the three previous studies lies in the measurement of variables that the researchers considered in previous studies that need to be entered and different analysis techniques. In previous studies analyzing the determinants of happiness in Brazil from two 
categories of variables, formed by other micro and macro variables by socioeconomic variables. Data from WVS and IPEA for 2006 and 2014 (Lilian Lopes Ribeiroa, 2007). Based on this study the authors conclude income is not the only determinant of the effect on the probability of happiness. From these findings, the authors look for other variables that are considered by the authors of these factors that can affect the probability of happiness. Further research per capita Gross Regional Domestic Product has a positive and significant effect on the happiness index of 33 provinces in Indonesia with a probability of 0,000 . This condition illustrates that the increase in Gross Regional Domestic Product per capita of 1 percent in each province affects 9.74 percent of the happiness index in the province. While economic growth and Gross Regional Domestic Product per capita simultaneously (simultaneous) can affect the happiness index with a probability value of F-statistics 0.0000 , meaning that if economic growth increases and accompanied by per capita Gross Regional Domestic Product in the 33 provinces (Amalia, 2017). From this study, the researchers used the panel data regression model, because it was considered the analysis technique of panel data regression models most suitable for use in the research of researchers. The latest research of this study provides empirical findings that the determinants of happiness in Indonesia are income, education, health, and social capital. This also indicates that in Indonesia there is no Easterlin paradox. Higher education will show higher happiness as well. The level of education that most influence on happiness is when someone has a higher education. The more healthy a person is, the greater his happiness. From these findings, the researcher wants to find out in Asia whether there is an Easterlin paradox in the variables that researchers consider to influence the happiness of people in Asia.

\section{RESEARCH METHODS}

This study uses secondary data from 28 countries in Asia during 20132017. The timeframe was chosen because of limited data sources and limited time available. This research uses panel data type. Sources of data used include 1. HDI in Asia, 2. Life expectancy in Asia, 3. Unemployment in Asia, in Asia, 4. HPI (Human Development Index) in Asia all data used is sourced from, 1. UNDP, 2 New Economic Foundation (NEF). The use of this HPI variable is because this HPI index is the best and most accurate of the 48 other indicators in the world, this indicator was created initially for the United Kingdom only. However, many countries have used HPI indicators to measure the happiness of their people.

The form of this research is descriptive with a quantitative approach which is to analyze and find out the level of welfare subjectively or in other words the happiness index in Asia based on HDI, life expectancy, and unemployment in 28 countries. Descriptive research according to (Suranto, 2009): "Research that aims to describe a particular social reality or is designed to gather information about real conditions that are taking place now". According to (E.G. Carmines, 2006) Quantitative research is: "research whose data are expressed in numbers and analyzed by statistical techniques". Reviewed based on the level of exploration, this study includes descriptive 
research and associative research/relationships. (Singarimbun, 1989) said that research according to the level of explanation is "research that aims to explain the position of the variables studied as well as the relationship between one variable with another variable." Here are some operational definitions of the variables that I used in this study:

- The level of happiness in this study used HPI from 28 Asian countries during 2013-2017. HPI data obtained from the well-being of respondents were allowed to imagine a ladder with 10 steps, where 0 (worst) to 10 (best), and environmental impact ecological footprint, environmental impact measured by human needs for nature.

- Welfare level, representing indicators of income, education, health expressed as indexes, longevity, healthy living, knowledge, and decent living standards.

- Unemployment, high unemployment caused by low education / few jobs. The data used are the unemployment index, the male workforce 15-24 who are not at work, and the female workforce 15-24 who are not at work.

- Life expectancy, higher life expectancy results in higher work productivity and enable higher-income too. Data used for life expectancy, taken from birth are expressed as indices using a minimum value of 20 years and a maximum value of 85 years.

The first thing to do is to do the F test to choose which model is the best, the $\mathrm{F}$ test is used to choose the PLS or FEM model technique by comparing the probability value of $\mathrm{F}$ on FEM with $\boldsymbol{\alpha}(1 \%, 5 \%$, or $10 \%)$ Hypothesis zero than F test is:

$\mathrm{HO}=$ Model PLS

$\mathrm{H} 1=$ Model FEM

If the probability value of $\mathrm{F}$ on $\mathrm{FEM}<\boldsymbol{\alpha}(1 \%, 5 \%$, or $10 \%)$, then Ho is rejected, so the use of the PLS model is considered inappropriate. The second conducted an LM test (lagrangian multiplier) which aims to choose between PLS and REM. The first step is to conduct an LM test by comparing the probability value of chi-square to $\boldsymbol{\alpha}(1 \%, 5 \%$, or $10 \%)$. The hypothesis for which is used to test the LM test is,

H0 = Model PLS

$\mathrm{H} 1$ = Model REM

If the LM test probability value is less than $\alpha(1 \%, 5 \%$, or $10 \%)$, then $\mathrm{H} 0$ is rejected, so the use of the PLS model is considered inappropriate. The results from the LM are then compared with the Hausman test. The next step is to carry out the Hausman test to determine the use of FEM or REM. Hausman testing by comparing the chi-square probability value with $\boldsymbol{\alpha}$ (1\%, $5 \%$, or $10 \%$ ) with the following hypothesis:

H0 = Model REM

If the probability value is less than $\alpha(1 \%, 5 \%$, or $10 \%)$, then $\mathrm{H} 0$ is rejected, so the model used in FEM. The method used to process and predict research results to obtain a conclusion. Panel data is defined by combining time-series data and cross-section data so panel data can provide more and more informative data (Beltagi, 2005). In general, panel data regression models can be done through three approaches, namely the common effect, 
fixed effect, and random effects approaches. The common effect model or Pooled Least Square (PLS), is the simplest panel data model approach because it only combines time-series data and cross-sections. In this model, time and individual dimensions are not considered, so it is assumed that corporate data behavior is the same over various periods. This method can use the Ordinary Least Square (OLS) approach or the least-squares technique to estimate the panel data model.

In general, panel data regression models can be done through three approaches, namely, the common effect, fixed effect, and random effects approach, described below.

- The common effect model is the simplest panel data model approach because it only combines time-series data and cross-sections. In this model, time and individual dimensions are not considered, so it is assumed that corporate data behavior is the same over various periods. This method can use the OLS approach to estimate the panel data model. The common effect model can be formulated as follows:

$$
\text { Yit }=\boldsymbol{\beta} 0+\boldsymbol{\beta} 1 \mathrm{X} 1 \text { it }+\boldsymbol{\beta} 2 \mathrm{X} 2 \text { it }+\boldsymbol{\beta} 3 \mathrm{X} 3 \text { it }+\mu \text { it }
$$

- The fixed-effect model (FE), this model assumes that differences between individuals can be accommodated from differences in their intercepts. To estimate the fixed effects model panel data using variable dummy techniques to capture intercept differences between companies, intercept differences can occur due to differences in work culture, managerial, and incentives. However, the slopes are the same between companies. This estimation model is often called the least squares dummy variable (LSDV) technique.

$$
\text { Yit }=\boldsymbol{\beta} 0+\boldsymbol{\beta} 1 \mathrm{X} 1 \text { it }+\boldsymbol{\beta} 2 \mathrm{X} 2 \text { it }+\boldsymbol{\beta} 3 \mathrm{X} 3 \text { it }+\mu \text { it }
$$

- Random effect model (REM), this model will estimate panel data where interruption variables may be interconnected between time and between individuals. In the random effect model, intercept differences are accommodated by the error terms of each company. The advantage of using the random effect model is to eliminate heteroscedasticity. This model is also called the Error Component Model (ECM) or the Generalized Least Square (GLS) technique. REM models are generally written as follows:

$$
\text { Yit }=\boldsymbol{\beta} 0+\boldsymbol{\beta} 1 \mathrm{X} 1 \text { it }+\boldsymbol{\beta} 2 \mathrm{X} 2 \mathrm{it}+\boldsymbol{\beta} 3 \mathrm{X} 3 \mathrm{it}+\mu \mathrm{it}+\varepsilon \mathrm{it}
$$

\section{RESULT AND DISCUSSION}

World Happiness Report (WHR) 2019 has just released its latest report related to the list of happy countries in the world. Again, Finland won the title of the happiest country in the world. Countries in the Scandinavia region occupy the top level with a total of 7,769 points. In the second place, Denmark followed with 7,600 points. Followed by Norway and Iceland on the third and fourth levels respectively. As well as Finland, Denmark, Norway, and Iceland, it is also located in the Scandinavian region. Of the 156 lists of countries released in the report, Indonesia is ranked 92nd with 5,192 points. In Southeast Asia, Indonesia lags behind Singapore, Thailand, the Philippines and Malaysia, and is above Vietnam, Cambodia, Laos, and Myanmar. 
According to (Sugiono, 2004) Descriptive analysis is a statistic used to analyze data by describing or describing the data that has been collected as it is without intending to make conclusions that apply to the public or generalizations.

Table 1. Indicators of HPI in Asia in 2013-2017 (Index)

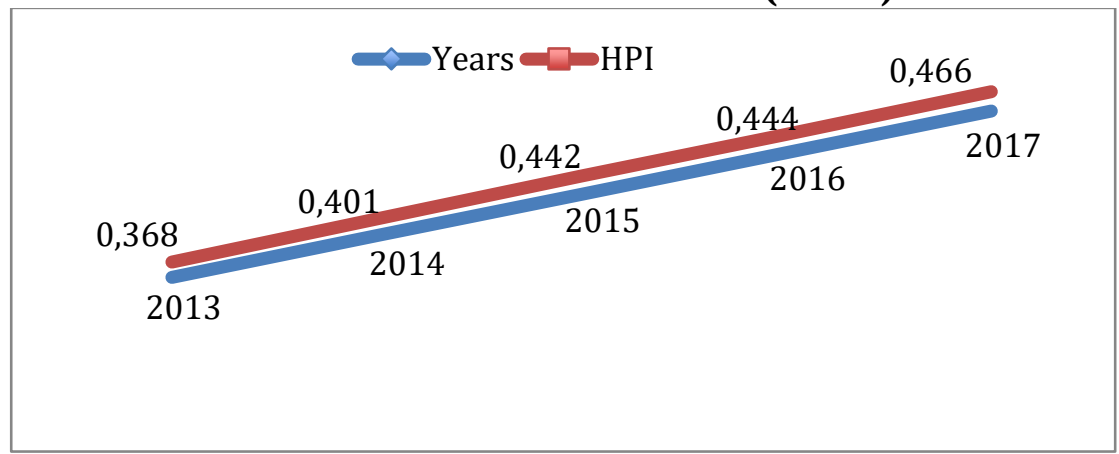

Figure 1 illustrates the indicators of HPI in Asia from 2013 to 2017 experiencing an increase every year, the highest number of HPI index in 2017 which was 0.466 .

Figure 2. Indicators of HDI (Human Development Index in Asia Year 2013 $-2017$

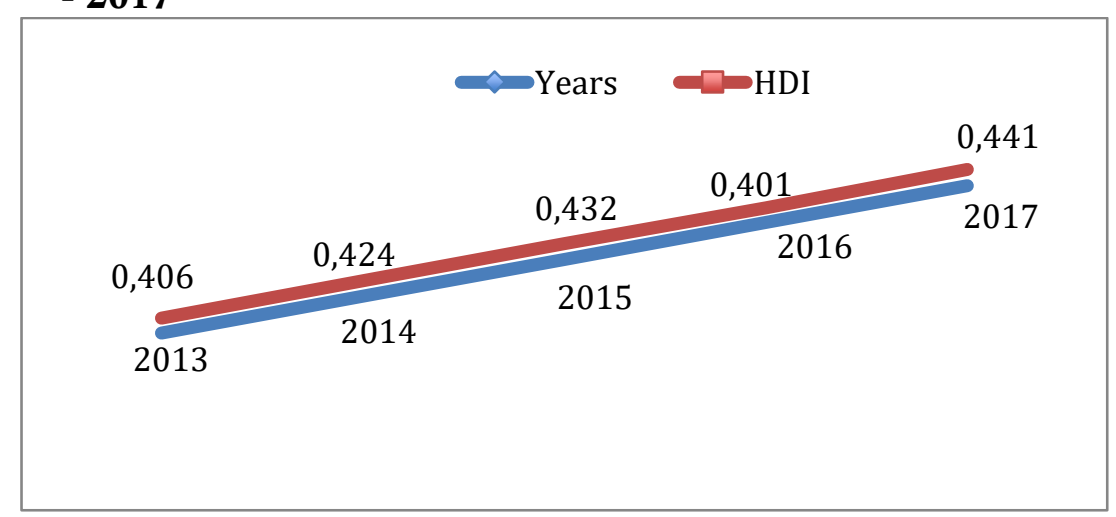

From figure 2 it can be seen that the amount of income in Asia for the period of 2013 to 2017 has increased. The highest number of HDI in 2017 was 0.441. This data is in the form of Index, HDI data sourced from UNDP.

Figure 3. Indicators of Life Expectancy in Asia in 2013-2017

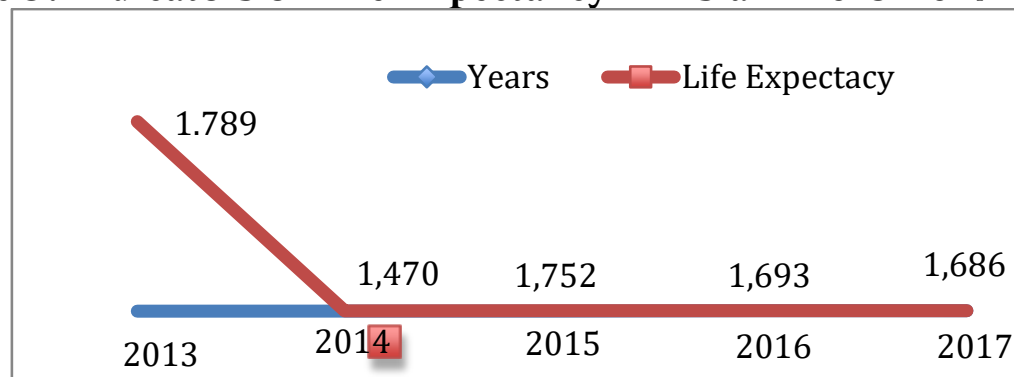


From figure 3 it can be seen that the number of life expectancy in Asia from 2013 to 2017 has increased. The highest increase in life expectancy indicators was in 2015 of 0.823.

Figure 4. Unemployment Indicators in Asia in 2013-2017

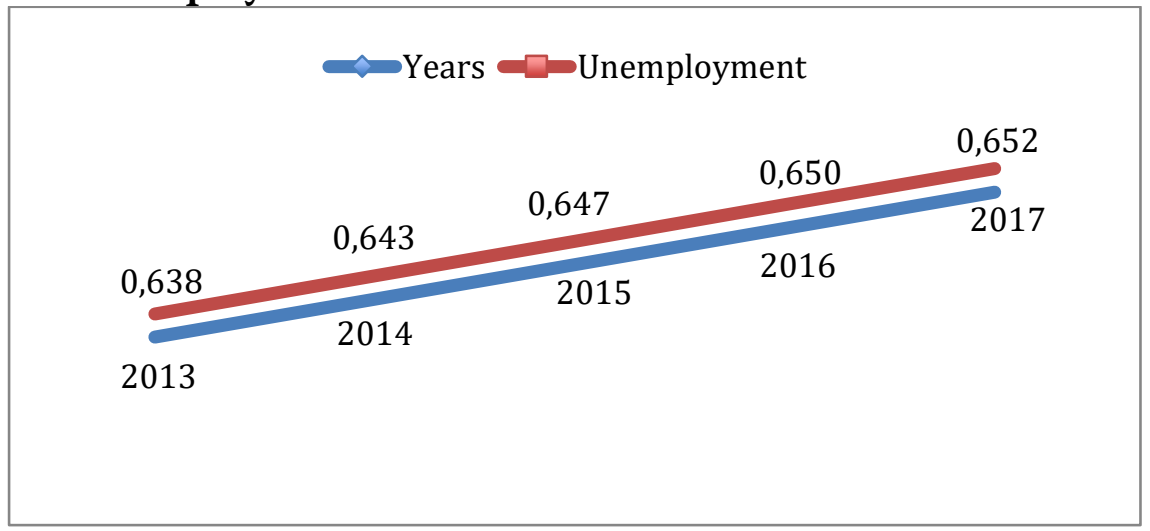

From figure 4 it can be seen that the number of unemployed people in Asia from 2013 to 2017 has increased. The highest increase in the unemployment indicator was in 2015 of 0.823 . It was only affected by income. other factors support the happiness index.

\section{Descriptive Statistics}

The following are descriptive results of HDI (X1), life expectancy (X2), unemployment (X3), and HPI (Y).

\section{Table 5. Descriptive Statistics Results}

\begin{tabular}{lllll}
\hline & & & $\begin{array}{l}\text { Life } \\
\text { expectancy }\end{array}$ & $\begin{array}{l}\text { Unemploym } \\
\text { ent }\end{array}$ \\
\hline Mean & 0.424077 & 0.420730 & 0.619757 & 1.812783 \\
Median & 0.416700 & 0.426000 & 0.640000 & 1.230000 \\
Maximum & 0.604900 & 0.695000 & 0.876000 & 16.00000 \\
Minimum & 0.200100 & 0.204000 & 0.349000 & 0.720000 \\
Std. Dev. & 0.092886 & 0.097311 & 0.141140 & 1.958959 \\
\hline
\end{tabular}

Descriptive statistical results obtained an average HPI of 0.421 , an average life expectancy of 0.620 , average unemployment of 1.813 , and an average HDI of 0.424 .

\section{Selecting the Regression Panel Model}

The following are the results of the panel regression model selection between the regression models between HDI, life expectancy, and unemployment. to happiness with the LM test, the Redundant Fixed Effect Test, and the Hausman Test.

\section{Table 6. LM Test}

\begin{tabular}{cccc}
\hline & \multicolumn{3}{c}{ Test Hypothesis } \\
& Cross-section & Time & Both \\
\hline Breusch-Pagan & 37.62324 & 19.04162 & 56.66486 \\
& 0 & 0 & 0 \\
\hline
\end{tabular}


The results of choosing a regression model with the LM test obtained a significance value of $0,000(p<0.05)$ meaning that the model chosen was the Random Effect Model.

Table 7. Results of the Redundant Fixed Effect Test (Chow Test)

\begin{tabular}{lrrr}
\hline Effects Test & Statistic & d.f. & Prob. \\
\hline Cross-section F & 11.487209 & $(22,87)$ & 0 \\
Cross-section & 156.654092 & 22 & 0 \\
Chi-square & & & \\
\hline
\end{tabular}

The results of the regression model selection with the Redundant Fixed Effect Test obtained a significance value of $0,000(p<0.05)$ meaning that the model chosen was the Fixed Effect Model. The results of choosing a regression model with the Hausman Test obtained a significance value of $0,000(p<0.05)$ meaning that the model chosen was the Fixed Effect Model. Based on the 3 tests conducted, the Fixed Effect model was obtained which was used in the study.

Table 8. Hausman Test

\begin{tabular}{llrrr}
\hline Test Summary & $\begin{array}{l}\text { Chi-Sq. } \\
\text { Statistic }\end{array}$ & Chi-Sq. d.f. & Prob. & \\
\hline Cross-section random & 58.870046 & 5 & 0 \\
\hline
\end{tabular}

\section{Fixed Effect Model}

The following are the results of the panel regression with the Fixed Effect Model between HDI, life expectancy, and unemployment for happiness.

Table 9. Results of the Fixed Effect Model

\begin{tabular}{ccccc}
\hline Variable & Coefficient & Std. Error & t-Statistic & Prob. \\
\hline C & -3.744038 & 0.648867 & -5.770117 & 0 \\
X1 & 0.104818 & 0.067005 & 1.564318 & 0.1214 \\
X2 & 1.088182 & 0.698915 & 1.55696 & 0.1231 \\
X3 & 0.004725 & 0.004944 & 0.955884 & 0.3418 \\
\hline
\end{tabular}

Based on the panel regression results described as follows:

a. The coefficient of the joint constant (-3.744) shows that without the influence of HDI, life expectancy, unemployment, the value of happiness is -3.744 .

b. HDI regression coefficient of 0.105 shows that each increase in the value of the HDI variable of 1 unit will have an impact of changes in the value of happiness of 0.105 units.

c. Life expectancy regression coefficient of 1.088 indicates that each increase in the value of the life expectancy variable of 1 unit will have an impact on increasing the value of happiness of 1.088 units.

d. The unemployment regression coefficient of -0.005 indicates that each increase in the value of the Unemployment variable of 1 unit will have an impact on the change in the value of happiness of -0.005 units. 


\section{Hypothesis Testing}

The following are the results of the hypothesis test for the panel regression model between HDI, life expectancy, and unemployment for happiness with the $\mathrm{F}$ test, the coefficient of determination, and the T-test.

\section{Table 10 Test Results F}

\begin{tabular}{cc}
\hline F-statistic & 22.54911 \\
\hline Prob(F-statistic $)$ & 0 \\
\hline
\end{tabular}

$F$ test results between HDI, life expectancy, and unemployment on happiness obtained statistical $F$ value $(22,549)$ and significance value $(0,000)$ less than alpha (0.050) so that it can be said that there is a significant influence between HDI, life expectancy, unemployment, and health on happiness together.

\section{Table 11. Coefficient of Determination}

\begin{tabular}{cc}
\hline R-squared & 0.874969 \\
\hline Adjusted R-squared & 0.836166 \\
\hline
\end{tabular}

The results of the coefficient of determination between HDI, life expectancy, and unemployment on happiness obtained value R2 (0.875) means that the happiness variable is influenced by HDI, life expectancy, and unemployment and the effect of each company is 87.5 percent in the model formed, while the effect on happiness by other factors outside of the study by 12.5 percent.

\section{Table 12. Test Results t}

\begin{tabular}{ccc}
\hline Variable & t-Statistic & Prob. \\
\hline $\mathrm{C}$ & -5.770117 & 0 \\
$\mathrm{X} 1$ & 1.564318 & 0.1214 \\
$\mathrm{X} 2$ & 1.55696 & 0.1231 \\
$\mathrm{X} 3$ & -0.955884 & 0.3418 \\
\hline
\end{tabular}

T-test results are described as follows:

a. The t-test results of the HDI variable obtained t-statistic value (1.564) with a significance value $(0.121)$ more than alpha $(0.050)$ so that there is no significant effect between income and happiness.

b. The t-test results of the life expectancy variable obtained t-statistic value (1.557) with a significance value (0.123) less than alpha (0.050) so that there is a significant influence between life expectancy on happiness.

c. T-test results of the unemployment variable obtained t-statistic value (0.956) with a significance value (0.342) more than alpha (0.050) so that there is no significant effect between unemployment on happiness.

\section{DISCUSSION}

This study uses samples from Asia because Asia is the largest continent and has the most populous population in the world with an area that covers $8.6 \%$ of the earth's surface, therefore researchers use Asian data that Asian researchers consider to be representative of the entire world. The results of this 
study used a panel data regression model.

Table 13: Data Processing

\begin{tabular}{ccccc}
\hline Variable & Koefisien & t-Statistic & Prob & Decision \\
\hline Konstanta ( C ) & -0.175725 & -2.012672 & 0,046 & - \\
HDI & 0.427989 & 5.788953 & 0,000 & Significance \\
Life expectancy & -0.009059 & -2.693446 & 0,008 & Significance \\
Unemployment & -0.310019 & -3.929541 & 0,001 & Significance \\
\hline
\end{tabular}

From table 13 the results of this study illustrate that 1 . HDI has a positive and significant effect on happiness, a probability of $(0,000)$. 2. Life expectancy is not much different from HDI which is significant for the happiness of (0.008). 3. Unemployment has a significant effect on happiness (0.001). Significant decisions come from probability values of less than (0.050).

Estimation results show that the determinants of happiness in Asia are HDI, life expectancy, and unemployment. The higher the HDI the higher the level of happiness. These results indicate the absence of the Easterlin paradox in Asian happiness. This finding is also in line with findings in many developing countries where HDI is still an important element in determining happiness.

Life expectancy has a positive impact on happiness. Efforts to improve health are inseparable from the improvement of a good life (Michalos, 2000). The relationship between health and happiness is still unclear. There may be a two-way relationship between the two. The more healthy people will be happier lives. The other side is the possibility that happy feelings will improve health (Perneger, 2004). However_(Diener, 2004) states that happy people are definitely healthy, but healthy people are not necessarily happy. Health is the strongest explanatory variable for life satisfaction (Kennedy, 1983). According to (Michalos, 2000) summarizes the positive relationship between subjective well-being with objective and subjective measures of health as discovered by (Campbell, 1976). Likewise found by (Rossi, 2013) that health perception is positively related to happiness.

Happiness is also positively influenced by the unemployment rate. Higher education opens up greater opportunities to establish relationships or a wider network, thereby opening up more open employment opportunities (Chen, 2012). Also, higher education allows one to get a better job so that the income he receives is higher. This makes increasing one's happiness (Cuñado, 2012). Education is often used as a proxy for earnings according to economists (David G. Blanchflower, 2004). The higher the education the higher the income or income. If income is still an important element in determining happiness, then the higher the education, the higher the income and the higher the happiness.

\section{CONCLUSION}

Based on the results of research and analysis of data that has been done about the effect of income, education, health on the level of happiness of people in Asia. The conclusion is as follows: Asia does not have an Easterlin paradox which can be seen from the results obtained in the three positive variables and 
significantly affect the happiness variable. This means that what influences someone's happiness is not an only income as said in the Easterlin Paradox, but other factors influence besides the income variable.

To increase the happiness index in every country in Asia, it is necessary to first increase the HDI, life expectancy index, and reduce the unemployment index. To improve HDI, there is a need to improve the quality of education in each country for high income earning facilities. As well as increased employment and employment opportunities. Thus the community can improve their welfare which then increases the ability of individuals to access facilities, proper education health, per capita expenditure, and increase happiness/welfare individually.

\section{REFERENCES}

Alex C. Michalos, B. D. (2000). Health and the Quality of Life. Springer.

Amalia, N. \&. (2017). Analisis Indeks Kebahagiaan Masyarakat Di 33 Provinsi Di Indonesia . Jurnal Ekonomi Dan Bisnis, Vol 14 No.3.

Bariyah, N. (2015). Analisis Indikator Fundamental Ekonomi Daerah Di Kalimantan barat; Pertumbuhan Ekonomi, pendapatan Perkapita, Dan HDI. Jurnal Ekonomi bisnis Dan Kewirausaan , 91.

Campbell, A. (1976). Subjective measures of well-being. American Psychologist, https://doi.org/10.1037/0003-066X.31.2.117.

Chen. (2012). Pendidikan. yeastgenome.org.

Clark, A. D. (2011). Will GDP Growth Increase Happiness In Developing Countries? The Institute For The Study Of Labor.

Clark, A. E. (2008). Relative Income Happiness, and Utility : An Explanation For The Easterlin Paradox And Other Puzzle. Journal Of Economic Literature 46, 95-144.

Cuñado, d. G. (2012). Does Education Affect Happiness? Evidence for Spain. reserchgate.net.

David G. Blanchflower, A. J. (2004). Well-being over time in Britain and the USA. www.elsevier.com/locate/econbase.

Diener. (2004). subjective Well-being. journal.Sagepub.com.

Dumairy. (1999). Matematika Terapan Untuk Bisnis dan Ekonomi . Yogyakarta: Bpfe.

E.G. Carmines, R. Z. (2006). Penelitian Kuntitatif . Jakarta: Sage.

Esterlin, R. (1995). Will Raising The Incomes Of All Increase The The Happiness Of All? Journal Of Economic Behavior And Organization 27, 3548.

Esterlin, R. (2001). Income And Happiness: Towards A Unified Theory. Economic Journal 111 (473), 465-484.

Frey, B. S. (2000). Happiness, Economy, And Institutions. Economic Joumal, Vol.110:918-938.

Gujarati, D. (2007). dasar-dasar Ekonometrika. jakarta: Erlangga.

Kennedy. (1983). A new look at interruptions. reserchgate.net.

Kuncoro. (2004:15). Ekonomi Pembangunan. Jakarta: Erlangga.

Lilian Lopes Ribeiroa, E. L. (2007). Gross National Happiness in Brazil: An analysis of its determinants. Economia, 156-167.

Michalos. (2000). Knowledge, Behavior, And Attitude. researchgate.net. 
Perneger. (2004). Health And Happiness In young Swiss adults. researchgate.net.

Rossi, G. (2013). Determinan Kebahagiaan di indonesia. ejournal.uksw.net, Volume 19 No. 1.

Samuelson. (1995). Economics, International Edition, Fifteen Edition. New York: Mc Graw Hill.

Seligman. (2015). Theory Of Health . Lib .Ui.Ac.Id.

Singarimbun, E. (1989). Metode Dan Proses Penelitian. Jakarta: LP3ES.

Sopiah. (2010). Metodologi Penelitian: Pendekatan Praktis Dalam Penelitian . Yogyakarta: Andi Offset.

Sugiono. (2004). Metode Penelitian Bisnis. Jakatra: Cv Alfa.

Sukirno, S. (2007). Makro Ekonomi Modern. Jakarta : Pt. Raja Grafindo.

Sukirno, s. (2008). Microeconomics Introduction Theory (P.67). Jakarta: Pt.Raja Grafindo Persada.

Sukirno, S. (2016). Makroekonomi Modern Ed 1 Cet 6. Jakarta: Rajawali Pers.

Suradi. (2012). Pertumbuhan Ekonomi Dan Kesejahteraan Sosial. Jurnal Ekonomi dan Bisnis.

Suranto. (2009). Metodologi Penelitian Dalam Pendidikan Dengan Program SPSS. Semarang: Cv. Ghyyas Putra.

Taringan, R. (2015:46). Ekonomi Regional "Teori Dan Aplikasi Edisi Revisi Cetakan Kedelapan. Jakarta: Bumi Aksara.

Tella, R. \&. (2005). Gross National Happiness As AN Answer to The Esterlin Paradox? Jel:D63;H00,I31,o00,Q3.

Todaro, M. \&. (2011). Pembangunan Ekonomi Edisi Kesebelas Jilid 1 . Jakarta : Erlangga.

UNDP), U. N. (2019, Juni 3). Http://Hdr.Undp.Org/En.

Ura, G. (2004). Gross National Happiness (GNS). Retrieved Juni 27, 2019, from gross national happiness: www.grossnationalhappiness.com

Veenhoven, R. (2006). Rising Happiness In Nation. Social Indicators Research Vol.79, Pp 421-436. 